2002s-25

What Type of Enterprise Forges

Close Links With Universities and Government Labs?

Evidence From CIS 2

Pierre Mohnen, Cathy Hoareau

Série Scientifique

Scientific Series

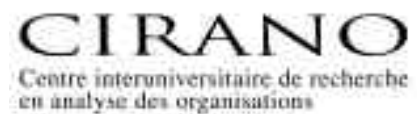

Montréal

Mars 2002 


\section{CIRANO}

Le CIRANO est un organisme sans but lucratif constitué en vertu de la Loi des compagnies du Québec. Le financement de son infrastructure et de ses activités de recherche provient des cotisations de ses organisationsmembres, d'une subvention d'infrastructure du ministère de la Recherche, de la Science et de la Technologie, de même que des subventions et mandats obtenus par ses équipes de recherche.

CIRANO is a private non-profit organization incorporated under the Québec Companies Act. Its infrastructure and research activities are funded through fees paid by member organizations, an infrastructure grant from the Ministère de la Recherche, de la Science et de la Technologie, and grants and research mandates obtained by its research teams.

\section{Les organisations-partenaires / The Partner Organizations}

-École des Hautes Études Commerciales

-École Polytechnique de Montréal

-Université Concordia

-Université de Montréal

-Université du Québec à Montréal

-Université Laval

-Université McGill

-Ministère des Finances du Québec

-MRST

-Alcan inc.

-AXA Canada

-Banque du Canada

-Banque Laurentienne du Canada

-Banque Nationale du Canada

-Banque Royale du Canada

-Bell Canada

-Bombardier

-Bourse de Montréal

-Développement des ressources humaines Canada (DRHC)

-Fédération des caisses Desjardins du Québec

-Hydro-Québec

-Industrie Canada

-Pratt \& Whitney Canada Inc.

-Raymond Chabot Grant Thornton

-Ville de Montréal

(C) 2002 Pierre Mohnen et Cathy Hoareau. Tous droits réservés. All rights reserved. Reproduction partielle permise avec citation du document source, incluant la notice $($ ).

Short sections may be quoted without explicit permission, if full credit, including $\odot$ notice, is given to the source.

Les cahiers de la série scientifique (CS) visent à rendre accessibles des résultats de recherche effectuée au CIRANO afin de susciter échanges et commentaires. Ces cahiers sont écrits dans le style des publications scientifiques. Les idées et les opinions émises sont sous l'unique responsabilité des auteurs et ne représentent pas nécessairement les positions du CIRANO ou de ses partenaires.

This paper presents research carried out at CIRANO and aims at encouraging discussion and comment. The observations and viewpoints expressed are the sole responsibility of the authors. They do not necessarily represent positions of CIRANO or its partners.

\section{ISSN 1198-8177}




\title{
What Type Of Enterprise Forges Close Links With Universities And Government Labs? Evidence From CIS 2*
}

\author{
Pierre Mohnen $n^{\dagger}$ and Cathy Hoareau
}

\begin{abstract}
Résumé / Abstract
Cette étude essaye de découvrir quels sont les facteurs économiques qui poussent les entreprises à chercher de l'information pour innover auprès des universités et des laboratoires publics de recherche ou à coopérer avec ces deux institutions. Nous nous servons des données de la seconde vague d'enquêtes communautaires d'innovation européennes (CIS2) pour l'Allemagne, la France, l'Espagne et l'Irlande. Nous estimons, d'une part, un modèle probit ordonné pour les universités et les laboratoires publics de recherche comme sources d'information, en contrôlant pour un biais de sélection et, d'autre part, un modèle probit trivarié pour les décisions successives d'innover, de collaborer et en particulier de collaborer avec les universités et les laboratoires publics de recherche, avec deux censures des données. Nous trouvons que les entreprises intensives en recherche et les innovateurs radicaux vont chercher de l'information auprès des universités et les laboratoires publics mais ne collaborent pas eux. Ces collaborations sont le fait de grandes firmes, d'entreprises breveteuses, et de celles qui reçoivent du support gouvermental pour innover. Des entreprises qui font partie d'un groupe ont tendance à collaborer mais pas nécessairement avec les universités et les laboratoires publics re recherche.

This paper tries to uncover some of the economic factors that encourage firms to seek information from universities and government labs or to collaborate with these institutions. We exploit the information contained in the second Community Innovation Surveys (CIS2) for France, Germany, Ireland and Spain. We estimate an ordered probit model on the importance of knowledge sourcing from universities and government labs controlling for selection bias, and a trivariate probit model explaining the innovation, collaboration in innovation, and collaboration with universities and government labs decisions with twice censored data. R\&D-intensive firms and radical innovators tend to source knowledge from universities and government labs but not to cooperate with them directly. Outright collaborations in innovation with universities and government labs is characteristic of large firms, firms that patent or those that receive government support for innovation. Members of an enterprise group tend to cooperate in innovation but not directly with universities or government labs.
\end{abstract}

Mots-clés : Innovation, collaborations universités-entreprises, laboratoires publics de recherche, sources d'information pour innover, CIS2

Keywords: Innovation, industry-university collaborations, knowledge sourcing, government labs, CIS2

\footnotetext{
*This paper grew out of a report to OECD and Statistics Canada. The first author also acknowledges the financial support of SSHRC. We thank Thierry Warin and Robert Dalpé for their helpful comments.

${ }^{\dagger}$ Université du Québec à Montréal, University Maastricht, MERIT and CIRANO

${ }^{\ddagger}$ CIRANO
} 


\section{INTRODUCTION}

The purpose of this study is to explore the factors that allow firms to benefit from knowledge developed in universities and government labs or that drive them to collaborate with these institutions. A number of studies have examined this question from various perspectives: the characteristics of the knowledge being transferred, the complementarity between the assets of the two parties involved in the collaboration, and the organizational aspects facilitating collaboration and knowledge transfer between firms and universities/research labs. Santoro and Gopalakrishnan (2000) review this literature and examine in particular the organizational dimension of industry-university collaborations. Hall, Link and Scott (2000) conclude from their analysis of partnerships in the U.S. Advanced Technology Program that universities are invited to collaborate with industry (as a contractor or as a research partner) in projects that involve new science, unknown technological territory. We shall focus on the economic determinants of collaboration and knowledge-sourcing from universities and government labs, factors such as size, group membership, degree of innovativeness, growth and government support.

Universities and government laboratories are more than private firms heavily involved in basic R\&D because it has the character of a public good. Many studies, starting with Mansfield (1980), estimate a high rate of return on basic R\&D. Adams (1990) estimates high spillover effects from academic R\&D. Jaffe (1989) and Acs, Audretsch and Feldman (1992) even find that the geographical proximity to universities increases innovation, be it measured by the degree of patenting or by the number of new products introduced in the market. Henderson, Jaffe and Trajtenberg (1998) find that university patents are more important (cited over a few generations of citations) and more general (cited in a broad range of fields) than the average patent. There is thus a fair amount of empirical evidence showing that academic institutions produce substantial R\&D spillovers.

Firms should therefore be interested in forging links, perhaps even in collaborating with universities or government laboratories in order to capture timely new technological opportunities stemming from basic research. Indeed, proximity to basic science is reported by Cohen (1995) to be one of the main determinants of innovation. Governments in their quest to maximize the social return of innovation should also be concerned with fostering such links between private firms and basic research institutions. Not all firms, though, are ready to seek such links and to be able to benefit from them. It would be interesting to know what profile of firm it takes, for instance size, group affiliation, or the presence of research activities, to seek close contacts and collaborate with centers of basic research. Knowing that, governments could focus their attention to this type of firms to maximize the efficiency in the allocation of public R\&D money.

The CIS2 (the second European Community Innovation Surveys) database contains two types of information regarding industry links with universities and government labs. One is about the role of universities or government labs as sources of information for innovation, and the other is about collaboration with universities or government labs. Given the other information about enterprises that is contained in the innovation surveys, we try to uncover some of the factors that encourage firms to interact with universities or government labs.

\section{DATA}

Our analysis of what determines the links between enterprises and universities/government laboratories is based on data from the Second Community Innovation Survey (CIS 2). Eurostat provided us with data from CIS2 in a micro-aggregated form for the manufacturing sectors of France, Germany, Ireland and Spain and for the service sectors of France, Germany and Ireland.

The data relate to innovation activities conducted in 1994-96. Firms which had introduced a technologically new or improved product or process, or which had unsuccessfully tried to do so or were still in the process of doing so during this period, were asked to fill out the full Innovation Survey questionnaire. Two questions are relevant for our study. One is about the sources of information for innovation, two of which are universities or higher education institutes (SUNI) and government or private non-profit research 
institutes (SGMT). We interpret this variable as revealing an active search by enterprises for information from those two sources in the innovation process. The other one is about collaboration in matters of innovation with each of these two sets of institutions that we shall name in the sequel universities and government labs. We only examine cooperation with national universities (CO61) and government labs (CO71). We do so because in all four countries national cooperation is by far the most important. Cooperation with foreign universities and government research institutes are often non-existent.

In a preliminary study we examined the determinants of the sources of information for innovation and of collaboration in innovation separately for universities and for government labs. Since the results were very similar for both, we decided to merge them and created two new variables:

- SBOTH, representing sources of information for innovation from universities or government labs. It takes the highest value of the ordinal variables SUNI and SGMT (that take the values 0 if irrelevant or 1 through 3 according to the degree of importance).

- $\mathrm{CBOTH}$, representing collaboration in innovation with national universities or national government labs. This is a dichotomous variable that takes the value of 0 if no collaboration exist with either of them and 1 if cooperation occurs with at least one of them. ${ }^{1}$

In our search for potential explanatory variables we are constrained by the set of variables for which we have data in CIS 2, the availability of those data for all countries, and the concern for exogeneity and parsimony. The variables we shall consider and their assumed effects are in order:

- Scientific sectors dummy. Each industry, because of its technology and the type of products it produces might have a different relationship with universities and governement labs in terms of knowledge outsourcing or outright research collaboration. For simplicity, we distinguish between firms that belong to scientific sectors, with a higher intensity of innovation and R\&D, and those that belong to more traditional industries. In the scientific sectors we have classified those that produce chemicals, machinery and equipment, vehicules, electrical and electronic products, computer services and engineering services. In these industries the $\mathrm{R} \& \mathrm{D} / \mathrm{sales}$ ratio was on average greater than $1.5 \%$ for all firms in our sample. The industry groups with their abbreviations are presented in appendix 1.

- Size. Size is measured by the logarithm of the number of employees. We expect bigger firms to have the minimum amount of qualified people, research effort, and overall connections to find it useful to establish contacts with universities and government laboratories. ${ }^{2}$

- Being part of a group. Firms that belong to a larger group might through this network be able to tap more easily information from universities/government labs or establish easier contacts with them. The argument is the same as for size, except that here it relates to an external scale effect. ${ }^{3}$

- Merger. We expect recently merged firms to benefit from access to universities and government labs because of their new partners, their more diversified knowledge base and their bigger size.

- Growth in employment. Growing firms are more likely to be dynamic, to hire researchers from universities or government research institutes, or to have the internal expertise that enables them to capture information from these institutions that is useful for innovation.

- Internal R\&D over sales. The higher the $R \& D$ intensity, the more we expect firms to feel the need to have ties with basic research, which tends to be conducted in universities and public research institutions.

- Innovation expenditures other than R\&D. This variable is defined as the ratio to sales of total innovation expenditures minus internal $R \& D$ expenses. It regroups acquisition of $R \& D$ services, acquisition of machinery and equipment linked to product and process innovations, industrial design,

${ }^{1}$ Universities and government labs received similar scores for the two questions. Only $15 \%$ of the respondents gave a different (categorical) answer to SUNI and SGMT and 7\% gave a different (binary) answer to CO61 and CO71. In other countries than the four of our sample, because of different national systems of innovation, firms may have different relationships with universities and with government labs. But to the extent that links with them are established in order to get access to basic research, a feature common to both of these institutions (more than for instance access to new talented labor), the two institutions are likely to play a similar role in all countries.

${ }^{2}$ We opt for the number of employees rather than sales to measure size, because the number of employees is more likely than sales to be exogenous because of its sluggish adjustments.

${ }^{3}$ Being part of a group means not being independent, but belonging to a consortium or a larger enterprise. 
training linked to technological innovation, and market introduction of technological innovations. We expect more innovative firms to have closer links with universities and government labs. Since innovation intensity on the output side (the share in sales of innovative products) is not available for services, we use the input side measure instead.

- Government support. Firms that receive government support, for instance national champions, are put in contact with basic research institutions, and encouraged if not obliged to collaborate with them.

- Being a radical innovator. A radical innovator is defined as one that has introduced on the market a product that was new for the market, as opposed to a product new for the firm but not for the market. We would expect radical innovators to be more in need of science and basic research conducted in universities or government labs.

- Patents applied for. Patent holders know more about basic research. They are therefore more able to absorb knowledge produced in universities and government laboratories and to collaborate with them. ${ }^{4}$

Among the firms that source knowledge or have outright collaborations with universities or government laboratories, product innovators are generally also process innovators and vice versa. We therefore could not exploit the type of innovation dichotomy. We would expect start-up firms to be spinoffs of universities/government labs and therefore have a privileged access to and collaboration experience with these institutions (as documented in the field of biotechnology by Zucker and Darby (1995)). Unfortunately, data on recently established firms is not available for France and Spain, whereas in Ireland it covers all the firms with knowledge sourcing from universities and government labs and would thus be a perfect predictor. We therefore could not examine this effect either.

We have eliminated all firms with a missing observation for one of our variables and all observations with growth in employment or labor productivity lower than $-50 \%$ and higher than $95 \%$, with $\mathrm{R} \& \mathrm{D} / \mathrm{sales}$ ratios higher than 50\%, and with log of labor productivity lower than 1.88 and higher than 7.69. Descriptive statistics on the firm samples in manufacturing and services are given in tables 1.a and 1.b. We notice that enterprises are on average bigger and more likely to belong to an enterprise group in manufacturing than in services. In contrast, manufacturing firms are less dynamic in various ways: on average they have a lower growth rate in employment, they more often receive government support and they have a lower R\&D/sales ratio.

As the services sample was rather small (around 10\% of the total), we decided to pool the data of manufacturing and services. Table 1.c gives some descriptive statistics on the pooled sample. Out of a total of 9191 firms (8 238 from manufacturing and 953 from services), $41 \%$ innovate, among which $66 \%$ draw some knowledge from universities/government labs. Among the innovating firms, $48 \%$ collaborate in their innovation activities, among which 56\% collaborate with universities/government labs. If we compare the means of our explanatory variables across subsamples, we notice that the frequency of firms belonging to the scientific sectors increases as we move from the full sample of firms to the sample of innovating firms, from the latter to the sample of collaborators in innovation and by yet another notch when we move to collaborations with universities/government labs specifically. The same can be said about average size and the frequency of government support in the various subsamples. Belonging to a group or doing R\&D is more frequent among innovating and collaborating firms, but not necessarily for those collaborating with universities or government labs.

\section{UNIVERSITIES OR GOVERNMENT LABORATORIES AS SOURCES OF INFORMATION}

The variable SBOTH had to be answered (by innovators only) on an ordered scale from 1 to 3 if the source of information was relevant, and by 0 if it was not relevant. The natural model to estimate in this case is a

${ }^{4}$ Data on mergers and patent applications are unavailable for Spain and radical innovations are only measured for manufacturing. When an explanatory variable is only available for a subset of firms, it takes a zero value for the other firms. Being a radical innovator should thus be understood as "being a radical innovator if in manufacturing", and likewise patents applied for means "patents applied for if in Ireland, France or Germany". 
probit model discriminating between innovating and non-innovating firms followed by a multinomial ordered probit model determining the strength of the links with universities/government labs. Our econometric model is thus as follows. Let us denote by INNO the binary variable that determines whether a firm innovates or not. ${ }^{5}$ To simplify notation, we shall omit the enterprise index. To the binary variable INNO corresponds a latent variable INNO*

$$
I N N O^{*}=X \beta+\varepsilon
$$

where $X$ is a matrix of explanatory variables, $\beta$ are the coefficients to be estimated and $\varepsilon$ is a random error term. To a zero response to INNO we associate a negative value for INNO*, and to a unity response to INNO we associate a positive value for INNO*. To the observed ordered responses to the variable SBOTH we associate a latent variable

$$
\operatorname{SBOTH}^{*}=Z \gamma+\eta
$$

where $Z$ is a matrix of explanatory variables, $\gamma$ is the coefficient to be estimated and $\eta$ is a random error term. The ordered responses to SBOTH correspond to intervals of realizations of the latent variables conditional on being an innovating firm. For instance,

$$
\begin{array}{ll}
\text { SBOTH=0 } & \text { if } \mathrm{INNO}=1 \text { and } S B O T H^{*} \leq t_{1} \\
\text { SBOTH=1 } & \text { if INNO=1 and } t_{1}<S B O T H^{*} \leq t_{2} \\
\text { SBOTH=2 } & \text { if INNO=1 and } t_{2}<S B O T H^{*} \leq t_{3} \\
\text { SBOTH=3 } & \text { if INNO=1 and } S B O T H^{*}>t_{3}
\end{array}
$$

We assume $\varepsilon$ and $\eta$ to be independently and identically jointly distributed according to a bivariate normal distribution with mean 0 , variance 1 and covariance $\rho$. We estimate the $\beta, \gamma$ and $\rho$ parameters by maximum likelihood, i.e. we maximize the likelihood of observing the $0 / 1$ responses on INNO and the ordered 0 to 3 responses to SBOTH that we observe in the whole sample. The log-likelihood function underlying the estimation of university/government laboratory as a knowledge source is given by :

$$
\begin{aligned}
& \ln L=\sum_{I N N O=0} \ln \left(\Phi_{1}[-X \beta]\right)+\sum_{I N N O=1, \text { SBOTH=0}} \ln \left(\Phi_{2}\left[t_{0}-Z \gamma, X \beta, \rho\right]\right)+ \\
& \sum_{I N N O=1, \text { SBOTH=1 }} \ln \left(\Phi_{2}\left[t_{1}-Z \gamma, X \beta, \rho\right]-\Phi_{2}\left[\left[t_{0}-Z \gamma, X \beta, \rho\right]\right)+\right. \\
& \sum_{I N N O=1, \text { SBOTH=2 }} \ln \left(\Phi_{2}\left[t_{2}-Z \gamma, X \beta, \rho\right]-\Phi_{2}\left[t_{1}-Z \gamma, X \beta, \rho\right]\right)+ \\
& \sum_{I N N O=1, \text { SBOTH=3 }} \ln \left(1-\Phi_{2}\left[t_{2}-Z \gamma, X \beta, \rho\right]\right)
\end{aligned}
$$

where $\Phi_{1}$ is the cumulative univariate normal distribution, $\Phi_{2}$ is the cumulative bivariate normal distribution, and the indices under the summation signs indicate the observations over which the sums are taken.

We pool the data of the manufacturing sectors of the four countries, and those of the services sectors for all countries but Spain. Any country heterogeneity that is not accounted for by the explanatory variables

\footnotetext{
${ }^{5}$ The variable INNO takes the value of one if either INPDT or INPCS for manufacturing and INSER for services takes the value of one. INPDT (INPCS) is the binary variable indicating the introduction of a technologically new or improved product (process). INSER is a binary variable indicating the introduction of a new or significantly improved service or method to produce or deliver it.
} 
introduced in the model is captured by country fixed effects introduced in the specification of the latent variables. The reference group pertains to the Spanish firms in the non-scientific sectors. The continuous variables $R \& D / s a l e s$, employment growth, size and other-than- $R \& D$ innovation expenditures/sales are expressed in deviations from the overall mean to have a scale similar to the binary variables.

Table 2 presents the estimates for the knowledge sourcing from universities/government labs. The model is estimated with and without industry dummies. Those are supposed to capture industry-specific influences for which we have no measure in this dataset (such as technological opportunity or industry-specific innovation incentives). In the absence of industry dummies, a scientific industry dummy is introduced to allow for an intercept shift for R\&D-intensive industries. The estimates with industry-specific effects and those which only distinguish between scientific and non-scientific industries are very similar. We find that firms in the scientific sectors innovate more frequently than firms in the more traditional sectors. The same can be said for larger firms and for firms that belong to a group. Growing firms, i.e. firms that show an increase in the number of their employees between 1994 and 1996, are also more frequently innovative than stagnant firms. Among the explanatory variables for knowledge sourcing, size, R\&D intensity, government support, patent applications and being a radical innovator increase the incidence of knowledge tapping from universities/government labs. The coefficient $\rho$ shows the correlation between the error terms (due to unaccounted for factors) in the probability to innovate and the intensity of knowledge sourcing equations. The correlation coefficient is not significant in both cases. The intensity of information sourcing from universities/government labs, which we observe for innovators only, is thus not subject to a selection bias, i.e. by some features that are particular to innovators and that would explain the degree of knowledge sourcing from universities/government labs.

In table 3 we report the marginal effects of the main explanatory variables, taken at their mean values. We only present the estimates with industry dummies since the comparison of the log likelihoods of both estimations shows that the specification with industry dummies is to be preferred. A one percent increase in size increases the probability of innovating by 13.6 percentage points, members of a group have a 9.5 percentage points higher probability of innovating, and a 1 percent higher growth rate in the past increases the probability of innovating by 11.3 percentage points. Firms involved in recent mergers have a lower probability of innovating. All explanatory variables with significant coefficients shift the distribution of categorical responses on the knowledge sourcing from universities/government labs from lower scores to higher scores. For example, a one percent increase in $\mathrm{R} \& \mathrm{D} / \mathrm{sales}$ increases by 7.7 percentage points the probability to consider universities or government labs as moderately important and by 14.2 percentage points the probability to consider them as relatively important.

Previous studies have found that small firms benefit more from university-based research spillovers than large firms, who rely more on their own R\&D (Link and Rees (1990), Acs et al (1994), Audretsch and Vivarelli (1994), Feldman (1994)). Our results are inconclusive in this regard, as we find that both larger size and more $R \& D$ are correlated with more sourcing of knowledge from universities. In any case, the externalities from basic research could be working indirectly rather than by way of knowledge borrowing by private enterprises. Small firms (incremental innovators or mere imitators) may benefit indirectly from university research by supplying inputs to large innovating firms, which derive knowledge from universities (Duguet (2000) has found evidence of such effects). The finding that R\&D intensity has a positive coefficient is in line with the absorptive hypothesis capacity (Cohen and Levinthal, 1990): you need to do some R\&D yourself to benefit from academic knowledge. Finally, the link between knowledge sourcing from universities or government labs and the occurrence of radical innovations has also been noticed by Baldwin and Da Pont (1996) with Canadian innovation survey data. Which way the causality goes, however, remains an open issue. To answer this question, we have to wait for the next round of innovation surveys to be able to conduct a vector autoregressive analysis.

\section{UNIVERSITIES OR GOVERNMENT LABORATORIES AS COLLABORATORS IN INNOVATION ACTIVITIES}


Although decisions on innovation and cooperation with various partners are probably taken simultaneously, the innovation survey questionnaire is structured as if these decisions were taken sequentially. First respondents have to tick whether they are innovative or not, then, if they declare themselves to be innovative, they have to tick whether they cooperate in innovation or not, and finally, if they cooperate, they have to indicate whether they do so with national universities or government labs or with other partners. A sequential model of innovation where the three choices are supposed to be taken in a sequence would posit a conditional independence between the individual decisions. ${ }^{6}$

Instead we model the data as obtained from a trivariate probit model with censoring. We assume three latent variables, $\mathrm{INNO}^{*}, \mathrm{CO}^{*}$ and $\mathrm{CBOTH}^{*}$ that are respectively determined by the following equations:

$$
\begin{aligned}
& I N N O^{*}=W_{1} \xi_{1}+v_{1} \\
& C O^{*}=W_{2} \xi_{2}+v_{2}
\end{aligned}
$$

and

$$
\mathrm{CBOTH}^{*}=W_{3} \xi_{3}+\mathrm{v}_{3}
$$

where $W_{i}, i=1,2,3$ are matrices of explanatory variables, and $\xi_{i}, i=1,2,3$ are the respective coefficients to be estimated. The error terms $v_{i}, i=1,2,3$ follow a trivariate standard normal distribution. ${ }^{7}$ The observed responses on INNO, $\mathrm{CO}$ and $\mathrm{CBOTH}$ are one if the corresponding latent variables are positive and zero otherwise. As we observe data on cooperation for innovators only and data on cooperation with universities/government labs for collaborators only, the likelihood function has four parts:

- to firms that do not innovate corresponds the likelihood $\mathrm{A} 1=\Phi_{1}\left(-W_{1} \xi_{1}\right)$,

- to firms that innovate but do not cooperate corresponds the likelihood A2 $=\Phi_{2}\left(W_{1} \xi_{1},-W_{2} \xi_{2}, \rho_{12}\right)$,

- to firms that innovate and cooperate but not with universities or government labs corresponds the likelihood A3 $=\Phi_{3}\left(W_{1} \xi_{1}, W_{2} \xi_{2},-W_{3} \xi_{3}, \rho_{12}, \rho_{13}, \rho_{23}\right)$,

- to firms that innovate and collaborate with universities or government labs corresponds the likelihood A $4=\Phi_{3}\left(W_{1} \xi_{1}, W_{2} \xi_{2}, W_{3} \xi_{3}, \rho_{12}, \rho_{13}, \rho_{23}\right)$,

where $\Phi_{1}$ is the cumulative univariate normal distribution function, $\Phi_{2}$ is the distribution function of a bivariate normal distribution, $\Phi_{3}$ is the distribution function of a trivariate normal distribution and $\rho_{i j}$ are the contemporaneous correlation coefficients between the error terms. When the error terms in the three equations (5) to (7) are uncorrelated, we have a sequential model of innovation. In that case, the bivariate or trivariate normal distributions are equal to the products of univariate distributions. Each decision is then taken as independent of previously taken decisions.

The log-likelihood function is thus given by

\footnotetext{
${ }^{6}$ As the number of explanatory variables are not the same for innovators and non-innovators, we cannot use a multinomial logit model with the four options of innovative behaviour (not innovate, innnovate but not cooperate, innovate and cooperate but not with univ/govt labs, innovate and cooperate with univ/govt labs). We could do so for the last three options, but then we would have a potential selection bias if we considered only innovators. In any case, the multinomial logit model by its underlying hypothesis of independence of irrelevant alternatives also posits some independence between the alternatives.

${ }^{7}$ Equation (1) and (5) have the same specification except for the distribution of the error term.
} 
$\ln L=$
$\sum_{I N N O=0} \ln \left(A_{1}\right)+\sum_{I N N O=1, C O=0} \ln \left(A_{2}\right)+\sum_{I N N O=1, C O=1, C B O T H=0} \ln \left(A_{3}\right)+\sum_{I N N O=1, C O=1, C B O T H=1} \ln \left(A_{4}\right)$

(8). ${ }^{8}$

In table 4 we report the estimated coefficients and the marginal effects of the corresponding variables. When estimating the system of equations with correlated error terms, the estimated correlation coefficients tended towards unity and only one coefficient turned out to be significant in the two collaboration equations. The correlation structure seemed to capture most of the explanatory power, hinting to the absence of common explanatory variables in the three equations. Since we did not have access to other explanatory variables at this stage, we preferred estimating the sequential model. Actually this one boils down to estimating each decision (innovation, cooperation, and cooperation with universities or government labs) separately. However, the marginal effects that we compute concern respectively one, two and three equations. As a result, the size of these effects diminishes as the number of simultaneous decisions increases. For instance, the effect of size on cooperation with universities is the product of the effects of size on the probability to innovate, to cooperate and to collaborate in particular with universities. The estimates are similar when the model is estimated with separate industry dummies or with just a dummy for the scientific industries. We only report the results obtained with a dummy characterizing the scientific sectors, to add some further summary explanation of the industry effects.

The results on the probit to innovate in table 4 are similar to those in table 2. This comes as no surprise since the error term of the probit equation in table 2 was basically uncorrelated with the error term in the sources of information from universities/government labs equation.

The probit on whether firms collaborate or not indicates that all our explanatory variables contribute positively to the probability of cooperating for innovation with various partners. Collaborations are more frequent in firms that belong to the scientific sectors, in larger firms, in firms that belong to a group, that receive government support for innovation, that are radical innovators, that patent and that spend larger amounts on innovation expenditures. The estimated coefficients of employment growth and merger occurrences are not significant. Our results are in line with the conclusions of Cassiman and Veugelers $(1999,2000)$ who also report a positive effect of size and own R\&D on R\&D cooperation with various partners using Belgian CIS1 data. A small difference with respect to their results is that we find that collaboration in innovation is more strongly correlated with innovation expenditures as a whole than merely with $R \& D$ expenditures. A one percentage point increase in innovation expenditures other than $R \& D$ increases by 23.3 percentage points the probability of cooperating in innovation whereas a one percentage point increase in $R \& D$ increases it only by some 13.4 percentage points.

The last probit equation discriminating between enterprises that collaborate with universities/government labs vs. other partners produces the most interesting results of this paper. Again all our explanatory variables contribute positively towards the explanation of this particular type of collaboration. A one percent increase in size increases by 1.6 percentage points the probability of collaborating with universities/government labs. Government supported firms have a 8.1 percentage points higher probability to collaborate with universities/government labs than firms without government support. Patenting firms have a $2 \%$ higher probability to collaborate with them than non-patenting firms, and firms in scientific sectors a 1.7\% higher probability. Firms that are part of a larger decision-taking unit and that do cooperate tend to rely less on collaborations with universities/industries than independent firms that cooperate. It may be that only the head firms of such larger units initiate these collaborations, whereas members are supposed to follow the leader and collaborate with academic institutions or basic research centers only via the headquarters. Collaborations with universities/government labs do not seem to be driven by recent growth or merger experience. What is strange is that neither R\&D-intensity, nor innovation-intensity, nor the fact of being a radical innovator, are significantly related to collaborations with universities/government labs. Leiponen (2001) obtains a positive size effect and also a positive research competence effect of R\&D collaborations with universities on Finnish innovation survey data. Adams, Chiang and Jensen (2000) also

${ }^{8}$ All estimations are performed using the software Gauss windows NT/95 version 3.5. 
report a larger size and larger R\&D effort for firms that are linked to federal labs via cooperative research and development agreements compared to those linked to other laboratories. Now, if we consider the joint decisions to innovate, collaborate at large and collaborate with universities/government labs specifically, we also find a positive effect of R\&D or innovation expenditures (see last column of table 4), but the positive correlation is mainly due to the decision to collaborate in general. 


\section{CONCLUSIONS}

The main conclusions we can draw from our analysis are that:

- Past growth helps in dissociating innovators from non-innovators but not at all in predicting links with universities or government labs as sources of information or collaboration partners.

- The fact of having recently been involved in a merger has nothing to do with links to universities or government labs.

- R\&D-intensive firms and radical innovators tend to source knowledge from universities and government labs but not to cooperate with them directly.

- Outright collaborations in innovation with universities and government labs is characteristic of large firms, firms that patent or those that receive government support for innovation.

- Members of an enterprise group tend to cooperate in innovation but not directly with universities/government labs. It is also not clear that they are more likely to tap knowledge from universities and government labs.

The following theoretical explanations could be given to these results. First, they are consistent with the absorption hypothesis that only firms that perform in-house $\mathrm{R} \& \mathrm{D}$ are able to extract knowledge from basic research institutions. Second, cultures in business and basic research institutions are too far apart to lead to cooperation unless the government establishes or forces a link. Firms that are supported by government to innovate are put in touch with and supposed to collaborate with universities and public research centers. Third, big size firms are more likely to have the means to attract competent researchers, to have an ongoing $R \& D$ program, and to set aside a budget for collaborations with basic science to derive benefits from it in a long-term perspective. Fourth, firms that are in touch with universities/government labs are likely to hold patents, because a patent portfolio might act as a signal of competence to get access to basic research performers.

We want to finish by raising two words of caution regarding the econometrics. Although we have tried to account for correlations between the error terms in the various decisions, no correlation showed up between the sources of knowledge for innovation and the probability of innovating, and too much correlation in some sense showed up in the collaboration model equations. Either there is a common missing story in the three equations or an identification issue. Another serious issue, common to most studies using innovation survey data, is the endogeneity of some of the explanatory variables, in particular size, R\&D and patenting. All three could cause as well as be caused by links with universitites/government labs. With cross-sectional data it is hard to identify causalities. It is also possible that some of the uncovered correlations might actually be due to joint correlations with other variables. Patenting, $R \& D$, innovation expenditures other than R\&D, collaborations with basic research institutions, size and growth might all be related in a systemic way feeding onto each other. Taking account of their simultaneity calls for a larger model with additional variables and data requirements. 


\begin{tabular}{|c|c|c|c|c|c|c|c|}
\hline \multicolumn{8}{|c|}{$\begin{array}{c}\text { Table 1.a Descriptive statistics } \\
\text { Pooled data of France, Germany, Ireland and Spain, 1994-1996 } \\
\text { CIS2 (manufacturing) }\end{array}$} \\
\hline In subsamples & \multirow[t]{2}{*}{ All firms } & \multicolumn{3}{|c|}{ Innovating firms } & \multicolumn{3}{|c|}{ Cooperating firms } \\
\hline & & All & $\begin{array}{c}\text { For } \\
\text { SUNI }=1,2,3\end{array}$ & $\begin{array}{c}\text { for } \\
\text { SGMT }=1,2,3\end{array}$ & All & $\begin{array}{c}\text { for } \\
\text { CO61 }=1\end{array}$ & $\begin{array}{c}\text { for } \\
\mathrm{CO} 71=1\end{array}$ \\
\hline Number of observations & 8,238 & 3,527 & 2,145 & 1,917 & 1,713 & 678 & 637 \\
\hline$\%$ of firms in scientific sectors & 0.337 & 0.504 & 0.552 & 0.536 & 0.564 & 0.634 & 0.600 \\
\hline Mean log of nb of employees & 4.659 & 5.301 & 5.498 & 5.442 & 5.684 & 6.002 & 5.895 \\
\hline$\%$ belonging to a group & 0.430 & 0.609 & 0.635 & 0.608 & 0.732 & 0.764 & 0.724 \\
\hline Mean growth in employment & 0.046 & 0.047 & 0.048 & 0.048 & 0.049 & 0.052 & 0.047 \\
\hline$\%$ with government support & - & 0.335 & 0.417 & 0.430 & 0.471 & 0.625 & 0.648 \\
\hline Mean R\&D/sales ratio & - & 0.028 & 0.030 & 0.030 & 0.032 & 0.038 & 0.038 \\
\hline $\begin{array}{c}\text { Mean of other innovation } \\
\text { expenditures/sales }\end{array}$ & - & 0.023 & 0.023 & 0.024 & 0.025 & 0.024 & 0.024 \\
\hline$\%$ of radical innovators & 0.238 & 0.557 & 0.585 & 0.597 & 0.618 & 0.642 & 0.647 \\
\hline$\%$ recent mergers & - & 0.067 & 0.075 & 0.074 & 0.080 & 0.091 & 0.091 \\
\hline$\%$ patents applied for & - & 0.339 & 0.396 & 0.365 & 0.410 & 0.459 & 0.455 \\
\hline France (in \%) & 0.446 & 0.444 & 0.378 & 0.334 & 0.508 & 0.525 & 0.447 \\
\hline Germany (in \%) & 0.098 & 0.166 & 0.220 & 0.215 & 0.119 & 0.063 & 0.177 \\
\hline Ireland (in \%) & 0.037 & 0.057 & 0.065 & 0.069 & 0.051 & 0.044 & 0.024 \\
\hline Spain (in \%) & 0.420 & 0.332 & 0.337 & 0.382 & 0.322 & 0.367 & 0.352 \\
\hline
\end{tabular}

\begin{tabular}{|c|c|c|c|c|c|c|c|}
\hline \multicolumn{8}{|c|}{$\begin{array}{c}\text { Table 1.b Descriptive statistics } \\
\text { Pooled data of France, Germany, and Ireland, 1994-1996 } \\
\text { CIS2 (services) }\end{array}$} \\
\hline Subsamples & All firms & & nnovating firm & & & perating fi & \\
\hline & & All & $\begin{array}{c}\text { For } \\
\text { SUNI }=1,2,3\end{array}$ & $\begin{array}{c}\text { for } \\
\text { SGMT }=1,2,3\end{array}$ & All & $\begin{array}{c}\text { for } \\
\text { CO61=1 }\end{array}$ & $\begin{array}{c}\text { for } \\
\mathrm{CO} 71=1\end{array}$ \\
\hline Number of observations & 953 & 241 & 138 & 110 & 96 & 45 & 33 \\
\hline$\%$ of firms in scientific sectors & 0.343 & 0.618 & 0.623 & 0.636 & 0.563 & 0.667 & 0.727 \\
\hline Mean log of nb of employees & 3.890 & 4.726 & 5.077 & 5.183 & 5.291 & 5.334 & 5.853 \\
\hline$\%$ belonging to a group & 0.293 & 0.465 & 0.471 & 0.500 & 0.531 & 0.511 & 0.485 \\
\hline Mean growth in employment & 0.066 & 0.096 & 0.095 & 0.080 & 0.074 & 0.064 & 0.011 \\
\hline$\%$ with government support & - & 0.224 & 0.290 & 0.327 & 0.365 & 0.556 & 0.576 \\
\hline Mean R\&D/sales ratio & - & 0.043 & 0.042 & 0.044 & 0.042 & 0.036 & 0.041 \\
\hline $\begin{array}{l}\text { Mean other innovation } \\
\text { expenditures/sales ratio }\end{array}$ & - & 0.028 & 0.032 & 0.033 & 0.029 & 0.038 & 0.041 \\
\hline$\%$ recent mergers & - & 0.087 & 0.101 & 0.082 & 0.125 & 0.111 & 0.152 \\
\hline$\%$ patents applied for & - & 0.199 & 0.246 & 0.273 & 0.323 & 0.444 & 0.546 \\
\hline France (in \%) & 0.408 & 0.291 & 0.196 & 0.264 & 0.354 & 0.378 & 0.485 \\
\hline Germany (in \%) & 0.407 & 0.539 & 0.638 & 0.582 & 0.438 & 0.533 & 0.485 \\
\hline Ireland (in \%) & 0.185 & 0.170 & 0.167 & 0.155 & 0.208 & 0.089 & 0.030 \\
\hline
\end{tabular}

Notes: SUNI: universities and higher education institutes as sources of information for innovation (if yes, ordered responses from 1 to 3); SGMT: government or private non-profit research institutes as sources of information for innovation (if yes, ordered responses from 1 to 3); CO61: collaboration in innovation with national universities or higher education institutions (binary responses, yes=1); CO71: collaboration with national government laboratories or private non-profit institutions (binary responses, yes $=1$ ). 


\begin{tabular}{|c|c|c|c|c|c|}
\hline \multicolumn{2}{|c|}{ Pooled data of France, Germany, Ireland and Spain, 1994-1996 } \\
CIS2 (manufacturing/services)
\end{tabular}

Notes: SBOTH: universities, higher education institutes, government or private non-profit research institutes as sources of information for innovation (if yes, ordered responses from 1 to 3); CBOTH: collaboration in innovation with national universities, higher education institutions, government laboratories or private non-profit institutions (binary responses, yes $=1$ ). 


\begin{tabular}{|c|c|c|}
\hline \multicolumn{3}{|c|}{$\begin{array}{l}\text { Pooled data of France, Germany, Ireland and Spain, 1994-1996 } \\
\text { CIS2 (manufacturing/services) }\end{array}$} \\
\hline Explanatory variables & Estimates with industry effects & Estimates without industry effects \\
\hline & \multicolumn{2}{|c|}{ Probit on innovation } \\
\hline Scientific sectors & - & $0.634(20.82)$ \\
\hline Log of number of employees & $0.373(25.38)$ & 0.385 (27.02) \\
\hline Belonging to a group & $0.262(7.32)$ & $0.252(7.24)$ \\
\hline Growth in employment & $0.309(3.76)$ & $0.311(3.90)$ \\
\hline \multirow[t]{2}{*}{ Recent merger } & $-0.064(-0.89)$ & $-0.051(-0.72)$ \\
\hline & \multicolumn{2}{|c|}{ Ordered probit on information from Universities/Government labs } \\
\hline Scientific sectors & - & $0.148(1.26)$ \\
\hline Log of number of employees & $0.156(2.35)$ & $0.161(2.52)$ \\
\hline Belonging to a group & $0.017(0.23)$ & $0.007(0.09)$ \\
\hline Growth in employment & $0.156(1.21)$ & $0.101(0.80)$ \\
\hline Government support & $0.530(11.76)$ & $0.540(12.0)$ \\
\hline Recent merger & $0.036(0.40)$ & $0.056(0.64)$ \\
\hline Patents applied for & $0.288(5.23)$ & $0.261(4.93)$ \\
\hline R\&D/sales & $1.627(3.23)$ & $1.098(2.25)$ \\
\hline Other-than-R\&D innov. expend/sales & $-0.243(-0.63)$ & $-0.285(-0.72)$ \\
\hline Being a radical innovator & $0.109(2.60)$ & $0.109(2.70)$ \\
\hline$\rho$ & $-0.037(-0.12)$ & $-0.059(-0.20)$ \\
\hline Log likelihood & -8192.86 & -8420.399 \\
\hline Number of observations & 9191 & 9191 \\
\hline
\end{tabular}

Note: bold = significant at $5 \%$ level. Asymptotic-t statistics in parentheses.

The estimated coefficients of the industry and country dummies in the probit and ordered probit and of the thresholds in the ordered probit are not reported. 
Table 3. Marginal effects of explanatory variables on probability to innovate and information sourcing for innovation (in percentage points)

Pooled data of France, Germany, Ireland and Spain, 1994-1996

CIS2 (manufacturing/services)

\begin{tabular}{|c|c|c|c|c|c|}
\hline \multirow{2}{*}{$\begin{array}{c}\text { Explanatory } \\
\text { variables }\end{array}$} & $\begin{array}{l}\text { Probability to } \\
\text { innovate }\end{array}$ & \multicolumn{3}{|c|}{ Intensity of information sourcing from universities/govt labs } \\
\hline $\begin{array}{c}\text { Log of number } \\
\text { of employees }\end{array}$ & 13.6 & -2.1 & 0.7 & 1.4 & 0.0 \\
\hline $\begin{array}{c}\text { Belonging to a } \\
\text { group }\end{array}$ & 9.5 & -0.2 & 0.1 & 0.1 & 0.0 \\
\hline $\begin{array}{c}\text { Growth in } \\
\text { employment }\end{array}$ & 11.3 & -2.1 & 0.7 & 1.4 & 0.0 \\
\hline $\begin{array}{c}\text { Recent merger } \\
\text { noyyyy} \\
\text { support }\end{array}$ & -2.3 & -0.5 & 0.2 & 0.3 & 0.0 \\
\hline $\begin{array}{c}\text { Patents applied } \\
\text { for }\end{array}$ & & -7.1 & 2.5 & 4.6 & 0.0 \\
\hline $\begin{array}{c}\text { R\&D/sales } \\
\text { Government }\end{array}$ & -21.9 & 7.9 & 14.2 & 0.0 \\
\hline $\begin{array}{c}\text { Other-than-R\&D } \\
\text { innovation } \\
\text { expend/sales }\end{array}$ & & 3.3 & -1.1 & -2.1 & 0.0 \\
\hline $\begin{array}{c}\text { Radical } \\
\text { innovator }\end{array}$ & & -1.4 & 0.5 & 0.9 & 0.0 \\
\hline
\end{tabular}

Note: The figures correspond to the estimates with industry effects. 


\begin{tabular}{|c|c|c|}
\hline \multicolumn{3}{|c|}{$\begin{array}{l}\text { universities/govt. labs } \\
\text { Pooled data of France, Germany, Ireland and Spain1994-1996 } \\
\text { CIS2 (manufacturing/services) }\end{array}$} \\
\hline \multirow[t]{2}{*}{ Explanatory variables } & Estimates & $\begin{array}{l}\text { Marginal effects in percentage points } \\
\text { on cumulative decisions }\end{array}$ \\
\hline & \multicolumn{2}{|c|}{ Probit on innovation } \\
\hline Scientific sectors & $0.751(24.19)$ & 28.9 \\
\hline Log of number of employees & 0.467 (31.92) & 18.0 \\
\hline Belonging to a group & $0.209(5.92)$ & 8.0 \\
\hline Growth in employment & $0.340(4.27)$ & 13.1 \\
\hline \multirow[t]{3}{*}{ Recent merger } & $-0.036(-0.48)$ & -1.4 \\
\hline & \multicolumn{2}{|c|}{ Probit on cooperation conditional on innovating } \\
\hline & & \\
\hline Scientific sectors & 0.148 (3.19) & 2.1 \\
\hline Log of number of employees & $0.193(9.34)$ & 2.7 \\
\hline Belonging to a group & $0.335(6.26)$ & 4.7 \\
\hline Growth in employment & $0.098(0.79)$ & 1.4 \\
\hline Government support & $0.744(15.16)$ & 10.4 \\
\hline R\&D/sales & $0.963(1.72)$ & 13.4 \\
\hline Being a radical innovator & $0.146(3.21)$ & 2.0 \\
\hline Recent merger & $0.108(1.21)$ & 1.5 \\
\hline Patents applied for & $0.137(2.40)$ & 1.9 \\
\hline \multirow[t]{2}{*}{ Other-than-R\&D innovation expend. } & $1.673(3.97)$ & 23.3 \\
\hline & \multicolumn{2}{|c|}{$\begin{array}{c}\text { Probit on cooperation with universities/govt. labs conditional on } \\
\text { innovating and cooperating }\end{array}$} \\
\hline Scientific sectors & $0.172(2.58)$ & 1.7 \\
\hline Log of number of employees & $0.110(3.86)$ & 1.6 \\
\hline Belonging to a group & $-0.188(-2.29)$ & 1.0 \\
\hline Growth in employment & $0.098(0.54)$ & 1.0 \\
\hline Government support & $0.803(12.17)$ & 8.1 \\
\hline $\mathrm{R} \& \mathrm{D} / \mathrm{sales}$ & $0.756(1.05)$ & 9.1 \\
\hline Being a radical innovator & $-0.022(-0.33)$ & 0.7 \\
\hline Recent merger & $0.184(1.49)$ & 1.5 \\
\hline Patents applied for & $0.257(3.19)$ & 2.0 \\
\hline Other-than-R\&D innovation expend. & $-0.619(-1.09)$ & 6.6 \\
\hline$\rho 12$ & 0 & \\
\hline$\rho 13$ & 0 & \\
\hline$\rho 23$ & 0 & \\
\hline Log of likelihood & -8084.12 & \\
\hline Number of observations & 9191 & \\
\hline
\end{tabular}

Note: bold $=$ significant at $5 \%$ level. Asymptotic-t statistics in parentheses.

The constant term and the estimated coefficients of the country dummies are not reported. 


\section{REFERENCES}

ACS, Z., D. AUDRETSCH and M. FELDMAN (1992), "Real effects of academic research: comment", American Economic Review, 82(1), 363-367.

ACS, Z., D. AUDRETSCH and M. FELDMAN (1994), "R\&D spillovers and recipient firm size", Review of Economics and Statistics, 67(2), 336-340.

ADAMS, J.D. (1990), "Fundamental stocks of knowledge and productivity growth", Journal of Political Economy, 98(41), 673-702.

ADAMS, J., E. CHIANG and J. JENSEN (2000), “The influence of federal laboratory R\&D on industrial research", NBER working paper 7612.

AUDRETSCH, D. and M. VIVARELLI (1994), "Small firms and R\&D spillovers: evidence from Italy", Revue d'Économie Industrielle, 67(1), 225-237.

BALDWIN, J. and M. DA PONT (1996), "Innovation in Canadian Manufacturing Enterprises", Statistics Canada, cat. 88-513.

CASSIMAN, B. and R. VEUGELERS (1999), "Spillovers and R\&D cooperation: Some empirical evidence", Cahiers de l'Innovation \#99003, CNRS.

CASSIMAN, B. and R. VEUGELERS (2000), "Complementarity in the innovation strategy: Internal R\&D, cooperation in R\&D, and external technology acquisition", mimeo.

COHEN, W. M. (1995), "Empirical studies of innovative activity", in P. Stoneman (ed.), Handbook of the Economics of Innovation and Technological Change, Blackwell Handbooks in Economics, 182-264.

COHEN, W. and D. LEVINTHAL (1990), "Absorptive capacity: a new perspective on learning and innovation"” Administrative Science Quarterly, 35, 128-152.

DUGUET, E. (2000), "Knowledge diffusion, technological innovation and TFP growth at the firm level: Evidence from French manufacturing", mimeo.

EUROSTAT (2000?), "Methodological Overview of CIS2 Data", mimeo.

FELDMAN, M. (1994), The Geography of Innovation. Kluwer Academic Publishers, Boston.

GREEN,W.H. (2000), Econometric Analysis. $4^{\text {th }}$ edition. Prentice-Hall Inc., New Jersey.

HALL, B., A. LINK and J. SCOTT (2000), “Universities as research partners”, NBER working paper 7643.

HECKMAN, J. (1979), "Sample selection bias as a specification error”, Econometrica, 47, 153-161.

HENDERSON, R., A. JAFFE and M. TRAJTENBERG (1998), "Universities as a source of commercial technology: A detailed analysis of university patenting, 1965-1988", Review of Economics and Statistics, 80(1), 119-127.

JAFFE, A.B. (1989), "Real effects of academic research", American Economic Review, 79(5), 957-970. 
LEIPONEN, A. (2001), "Why do firms not collaborate? Competencies, R\&D collaboration, and innovation under different technological regimes", in Innovation and Firm Performance. Econometric Explorations of Survey Data (A. Kleinknecht and P. Mohnen, eds.). Palgrave, London.

LINK, A.N. and J. REES (1990), "Firm size, univrsity-based research, and the returns to R\&D", Small Business Economics, 3, 1-38.

MANSFIELD, E. (1980), "Basic research and productivity increase in manufacturing", American Economic Review, 70, 863-873.

ROESSNER, D. and A. BEAN (1994), "Patterns of industry intercation with federal laboratories", Journal of Technology Transfer, December, 59-77.

SANTORO, M. and S. GOPALAKRISHNAN (2000), "The institutionalization of knowledge transfer activities within industry-university collaborative ventures", Journal of Engineering and Technology Management, 17, 299-319.

THOMAS, A. (2000), Économétrie des variables qualitatives. Dunod, Paris.

ZUCKER, L. and M. DARBY (1995), "Virtuous circles of productivity: star bioscientists and the institutional transformation of industry", NBER working paper 5342. 


\section{Appendix 1}

\section{Industry definitions}

\begin{tabular}{|c|c|c|}
\hline $\begin{array}{l}\text { Industry } \\
\text { Abbreviation }\end{array}$ & $\begin{array}{l}\text { NACE } \\
\text { code } \\
\text { (rev.1) }\end{array}$ & Industry definition \\
\hline \multicolumn{3}{|l|}{ Manfacturing } \\
\hline FOOD & $15-16$ & manufacture of food, beverages and tobacco \\
\hline TEXTILE & $17-19$ & $\begin{array}{l}\text { manufacture of textiles, wearing apparel, dressing and dyeing of } \\
\text { fur, tannings and dressing of leather, luggage, handbags, saddlery, } \\
\text { harness and footwear }\end{array}$ \\
\hline WOOD & $20-22$ & $\begin{array}{l}\text { manufacture of wood and products of wood and cork, except } \\
\text { furniture, manufacture of straw and plaiting materials, pulp, paper, } \\
\text { and paper products, publishing, printing, and reproduction of recorded media }\end{array}$ \\
\hline CHEM & 23-24 & $\begin{array}{l}\text { manufacture of coke, refined petroleum products and nuclear fuel, } \\
\text { manufacture of chemicals and chemical products }\end{array}$ \\
\hline PLASTIC & 25 & manufacture of rubber and plastic products \\
\hline NON-MET & 26 & manufacture of other non-metallic mineral products \\
\hline METAL & $27-28$ & $\begin{array}{l}\text { manufacture of basic metals, fabricated metal products, except } \\
\text { machinery and equipment }\end{array}$ \\
\hline M\&E & 29 & manufacture of machinery and equipment NEC \\
\hline ELEC & $30-33$ & $\begin{array}{l}\text { manufacture of office machinery and computers, electrical } \\
\text { machinery and apparatus, radio, television and communication } \\
\text { equipment and apparatus, medical, precision and optical } \\
\text { instruments, watches and clocks }\end{array}$ \\
\hline VEHIC & 34-35 & $\begin{array}{l}\text { manufacture of motor vehicles, trailers, semi-trailers, and other } \\
\text { transport equipment }\end{array}$ \\
\hline NEC & 36 & manufacture of furniture, manufacturing NEC \\
\hline
\end{tabular}

$\underline{\text { Services }}$

$\begin{array}{lll}\text { SUPPLIES } & 40-41 & \text { electricity, gas and water supply } \\ \text { WHOLES } & 51 & \text { wholesale } \\ \text { TRANSP } & 60-62 & \text { transport } \\ \text { TELECOM } & \mathbf{6 4} & \text { telecommunications } \\ \text { FINANCE } & 65-67 & \text { financial intermediation } \\ \text { COMPUT } & \mathbf{7 2} & \text { computer and related activities } \\ \text { ENGINEE } & \mathbf{7 4} & \text { engineering services }\end{array}$

N.B. Industries in bold are classified among the scientific sectors. 


\section{Liste des publications au CIRANO*}

\section{Série Scientifique / Scientific Series (ISSN 1198-8177)}

2002s-25 What Type of Enterprise Forges Close Links With Universities and Government Labs? Evidence From CIS 2 / Pierre Mohnen et Cathy Hoareau

2002s-24 Environmental Performance of Canadian Pulp and Paper Plants : Why Some Do Well and Others Do Not ? / Julie Doonan, Paul Lanoie et Benoit Laplante

2002s-23 A Rule-driven Approach for Defining the Behavior of Negotiating Software Agents / Morad Benyoucef, Hakim Alj, Kim Levy et Rudolf K. Keller

2002s-22 Occupational Gender Segregation and Women's Wages in Canada: An Historical Perspective / Nicole M. Fortin et Michael Huberman

2002s-21 Information Content of Volatility Forecasts at Medium-term Horizons / John W. Galbraith et Turgut Kisinbay

2002s-20 Earnings Dispersion, Risk Aversion and Education / Christian Belzil et Jörgen Hansen

2002s-19 Unobserved Ability and the Return to Schooling / Christian Belzil et Jörgen Hansen

2002s-18 Auditing Policies and Information Systems in Principal-Agent Analysis / MarieCécile Fagart et Bernard Sinclair-Desgagné

2002s-17 The Choice of Instruments for Environmental Policy: Liability or Regulation? / Marcel Boyer, Donatella Porrini

2002s-16 Asymmetric Information and Product Differentiation / Marcel Boyer, Philippe Mahenc et Michel Moreaux

2002s-15 Entry Preventing Locations Under Incomplete Information / Marcel Boyer, Philippe Mahenc et Michel Moreaux

2002s-14 On the Relationship Between Financial Status and Investment in Technological Flexibility / Marcel Boyer, Armel Jacques et Michel Moreaux

2002s-13 Modeling the Choice Between Regulation and Liability in Terms of Social Welfare / Marcel Boyer et Donatella Porrini

2002s-12 Observation, Flexibilité et Structures Technologiques des Industries / Marcel Boyer, Armel Jacques et Michel Moreaux

2002s-11 Idiosyncratic Consumption Risk and the Cross-Section of Asset Returns / Kris Jacobs et Kevin Q. Wang

2002s-10 The Demand for the Arts / Louis Lévy-Garboua et Claude Montmarquette

2002s-09 Relative Wealth, Status Seeking, and Catching Up / Ngo Van Long, Koji Shimomura

2002s-08 The Rate of Risk Aversion May Be Lower Than You Think / Kris Jacobs

2002s-07 A Structural Analysis of the Correlated Random Coefficient Wage Regression Model / Christian Belzil et Jörgen Hansen

2002s-06 Information Asymmetry, Insurance, and the Decision to Hospitalize / Åke Blomqvist et Pierre Thomas Léger

\footnotetext{
* Consultez la liste complète des publications du CIRANO et les publications elles-mêmes sur notre site Internet :
} 
2002s-05 Coping with Stressful Decisions: Individual Differences, Appraisals and Choice / Ann-Renée Blais

2002s-04 A New Proof Of The Maximum Principle / Ngo Van Long et Koji Shimomura

2002s-03 Macro Surprises And Short-Term Behaviour In Bond Futures / Eugene Durenard et David Veredas

2002s-02 Financial Asset Returns, Market Timing, and Volatility Dynamics / Peter F. Christoffersen et Francis X. Diebold

2002s-01 An Empirical Analysis of Water Supply Contracts / Serge Garcia et Alban Thomas

2001s-71 A Theoretical Comparison Between Integrated and Realized Volatilities Modeling / Nour Meddahi

2001s-70 An Eigenfunction Approach for Volatility Modeling / Nour Meddahi

2001s-69 Dynamic Prevention in Short Term Insurance Contracts / M. Martin Boyer et Karine Gobert

2001s-68 Serial Cost Sharing in Multidimensional Contexts / Cyril Téjédo et Michel Truchon

2001s-67 Learning from Strike / Fabienne Tournadre et Marie-Claire Villeval

2001s-66 Incentives in Common Agency / Bernard Sinclair-Desgagné

2001s-65 Detecting Mutiple Breaks in Financial Market Volatility Dynamics / Elena Andreou et Eric Ghysels

2001s-64 Real Options, Preemption, and the Dynamics of Industry Investments / Marcel Boyer, Pierre Lasserre, Thomas Mariotti et Michel Moreaux

2001s-63 Dropout, School Performance and Working while in School: An Econometric Model with Heterogeneous Groups / Marcel Dagenais, Claude Montmarquette et Nathalie Viennot-Briot

2001s-62 Derivatives Do Affect Mutual Funds Returns : How and When? / Charles Cao, Eric Ghysels et Frank Hatheway

2001s-61 Conditional Quantiles of Volatility in Equity Index and Foreign Exchange Data / John W. Galbraith, Serguei Zernov and Victoria Zinde-Walsh

2001s-60 The Public-Private Sector Risk-Sharing in the French Insurance "Cat. Nat. System" / Nathalie de Marcellis-Warin et Erwann Michel-Kerjan

2001s-59 Compensation and Auditing with Correlated Information / M. Martin Boyer et Patrick González

2001s-58 Resistance is Futile: An Essay in Crime and Commitment / M. Martin Boyer

2001s-57 The Unreliability of Output Gap Estimates in Real Time / Athanasios Orphanides et Simon van Norden

2001s-56 Exact Nonparametric Two-Sample Homogeneity Tests for Possibly Discrete Distributions / Jean-Marie Dufour et Abdeljelil Farhat

2001s-55 Les coûts de la réglementation : une revue de la littérature / Robert Gagné, Paul Lanoie, Pierre-Carl Micheud et Michel Patry

2001s-54 Testing for structural Change in the Presence of Auxiliary Models / Eric Ghysels et Alain Guay

2001s-53 Environmental Regulation and Productivity: New Findings on the Porter Hypothesis / Paul Lanoie, Michel Patry et Richard Lajeunesse 